\title{
Hubungan Berat Badan Lahir Bayi dan Infeksi Nosokomial di ruang Perinatologi
}

\author{
Eviana S Tambunan*
}

\begin{abstract}
Abstrak
Infeksi nosokomial masih merupakan masalah kesehatan di seluruh dunia karena meningkatkan angka kematian. Infeksi nosokomial paling tinggi ditemukan di ruang perawatan bayi dan angka infeksi tertinggi terjadi di ruang perawatan intensif neonatus. Penelitian ini bertujuan mengetahui hubungan antara berat badan lahir bayi dengan kejadian infeksi nosokomial. Penelitian ini menggunakan data sekunder rekam medik bayi yang dirawat di level III Perinatologi RSAB Harapan Kita. Desain studi yang digunakan adalah Kasus Kontro dengan metode analisis regresi logistik ganda. Penelitian ini menemukan jenis infeksi nosokomial terbanyak adalah sepsis $(52,91 \%)$, bakteremia $(35,48 \%)$ dan pneumonia $(11,61 \%)$. Pola jenis kuman yang paling banyak ditemukan adalah bakteri gram negatif (0,3 -53,9\%). Jenis kuman terbanyak adalah Serratia sp (2,3-38,1\%), Klebsiella pneumonia (kisaran 3,2-6,8\%) dan Candida sp. (1\%$4,2 \%$ ). Penelitian ini menemukan kejadian infeksi nosokomial berhubungan dengan pemasangan long line intravenous catheter dan/atau kateter umbilikus. Neonatus dengan berat badan $<2500$ gram yang menggunakan long line intravenous catheter dan/atau kateter umbilikus berisiko tinggi untuk menderita infeksi nosokomial. Risiko juga meningkat pada neonatus dengan berat badan lahir $\geq 2500$ gram, sementara neonatus dengan dengan berat badan $<2500$ gram yang hanya menggunakan infus, tidak berisiko mengalami infeksi nosokomial.
\end{abstract}

Kata kunci: Berat badan lahir, Infeksi nosokomial, Ruang perinatologi.

\begin{abstract}
Nosocomial infection is still a health problem on the world because of its increasing morbidity and mortality rates. Nosocomial infection is mostly occured among infant and the highest infection is in the neonatus intensive care unit. The objective of the study is to examine the relationship between birth weight and nosocomial infection of neonates (pneumonia, bacteremia and septicemia) in level III, Perinatal Ward, Rumah Sakit Anak Bersalin Harapan Kita (RSAB Harapan Kita) in the period of 2002-2004. The data used was the medical record of infants under care in level III, Perinatal Ward, RSAB Harapan Kita. Major sites of infection were septicemia (52.91\%), bacteremia (35.48\%) and pneumonia (11.61\%). The most commonly found pathogens were Gram-negative bacteria: Serratia sp. (range 2.3\%-38.10\%), Klebsiella pneumonia (range 3,2\%-6,8\%) and Candida sp. (1\%-4,2\%). Neonates with birth weight <2500 gram using long line intravenous catheter and/or umbilical catheter faced high risk of nosocomial infection. Neonates with birth weight $<2500$ gram having intravenous catheter showed no case of nosocomial infection.
\end{abstract}

Key words : Birth weight, Nosocomial infection, Perinatal Ward. 
Infeksi nosokomial masih merupakan masalah kesehatan di seluruh dunia karena meningkatkan angka morbiditas dan mortalitas. Infeksi nosokomial paling tinggi terjadi di ruang perawatan anak kurang dari satu tahun dan angka infeksi tertinggi terjadi di ruang perawatan intensif neonatus, Penelitian yang dilakukan oleh Shon et $a l,{ }^{1}$ dalam suatu survey point prevalence di NICU pada rumah sakit di Columbia dan Kanada, didapatkan bahwa bayi dengan berat badan $\leq 1500$ gram memiliki risiko 2,69 kali lebih besar (95\% CI 1,75-4,14; $p<0,001)$ untuk terjadi infeksi nosokomial dibandingkan bayi dengan berat badan $>1500$ gram. Pada rumah sakit tersebut juga didapatkan neonatus yang dirawat di NICU mengalami infeksi aliran darah sebesar $52,6 \%$, sebagai infeksi nosokomial terbanyak, yang diikuti dengan infeksi nosokomial pneumonia sebesar $12,9 \%$.

Kejadian infeksi nosokomial pada bayi di ruang perawatan intensif dihubungkan dengan berat badan lahir bayi. Beberapa faktor risiko meliputi data demografi (umur dan jenis kelamin), pemakaian alat-alat invasif, tindakan prosedur operasi, penggunaan antibiotika, tempat/lokasi infeksi, lamanya perawatan, tingkat keparahan penyakit, dan adanya kelainan kongenital serta umur kehamilan kurang dari 37 minggu. Rujukan dan sosial ekonomi keluarga juga merupakan faktor risiko infeksi nosokomial. Faktor risiko yang juga sangat berperan terhadap terjadinya infeksi nosokomial adalah prilaku dan sikap tenaga kesehatan di rumah sakit.

Salah satu rumah sakit khusus perawatan intensif neonatus rujukan di Indonesia adalah Rumah Sakit Anak dan Bersalin Harapan Kita (RSAB Harapan Kita). Hasil penelitian epidemiologi deskriptif infeksi nosokomial di ruang rawat inap anak RSAB Harapan Kita, tahun 19971999 yang dilakukan oleh Rahayu ${ }^{2}$ memperlihatkan adanya peningkatan dari tahun 1996(2\%) sampai dengan 1999 (2,18), Namun, insiden kejadian infeksi nosokomial di ruang rawat intensif/perinatologi neonatus belum diketahui secara pasti, begitupula hubungannya dengan berat badan lahir bayi.

\section{Metode}

Studi menggunakan data sekunder rekam medik bayi yang dirawat di ruang perinatologi (level III) pada periode Januari 2002 sampai dengan Desember 2004. Lokasi penelitian adalah ruang Perinatologi RSAB Harapan Kita yang terdiri dari ruang rawat Seruni dan Kemuning yang dilengkapi peralatan inkubator dan respirator diperuntukkan bagi neonatus yang memerlukan perawatan intensif. Populasi sumber adalah seluruh neonatus yang lahir hidup. Populasi studi adalah seluruh neonatus yang lahir hidup dan dirawat di ruang Perinatologi RSAB Harapan Kita pada periode Januari 2002 sampai dengan Desember 2004. Sampel adalah bayi yang dirawat di ruang Seruni dan Kemuning yang berjumlah 310 bayi meliputi 155 kasus dan 155 kontrol. Kasus adalah bayi yang dirawat di ruang perawatan perinatologi minimal 3 hari, infeksi pada lokasi sama ditemukan mikroorganisme yang berbeda dari yang ditemukan ketika masuk rumah sakit, menunjukkan gejala klinis infeksi nosokomial. Pada hasil biakan mikroorganisme ditemukan positif mengandung mikroorganisme penyebab infeksi nosokomial, bayi terinfeksi dengan lebih dari satu infeksi nosokomial akan dihitung satu. Kontrol adalah: bayi dirawat di ruang perawatan perinatologi, minimal 3 hari dengan penyakit lain, namun tidak menunjukkan gejala klinis infeksi nosokomial, dari hasil pembuktian satu atau lebih biakan mikroorganisme terbukti steril.

\section{Hasil}

Jenis infeksi nosokomial yang banyak dialami oleh neonatus adalah sepsis, sekitar $57,6 \%$ terjadi pada neonatus dengan berat badan lahir $<2500$ gram dan $49,4 \%$ pada neonatus dengan berat badan $\geq 2500$ gram. Jenis kuman yang paling banyak adalah bakteri gram negatif (kisaran 0,3\%-53,9\%) dengan jenis kuman terbanyak adalah Serratia sp (kisaran 2,3\%-38,1\%), K pneumonia $(3,2 \%-6,8 \%)$ dan Candida (1\%-4,2\%).

\section{Identifikasi Kandidat Model}

Variabel independen yang memenuhi kriteria kandidat model multivariate adalah jenis kelamin, kelainan kongenital, status seksio, lahir luar, lama reawat, Penggunaan ETT, kateter umbilikus, NGT, dan kataer arteri (nilai $\mathrm{p} \leq 0,25$ ) Lihat tabel 1 .

Terlihat bahwa pada variabel penggunaan long line intravenous catheter/kateter umbilikus baik sebelum dikontrol maupun setelah dikontrolan dengan variabel umur kehamilan, umur neonatus dan lama hari rawat terdapat perbedaan OR antar strata yang cukup besar

Tabel 1. Identifikasi Kandidat Model dengan Analisis Bivariat

\begin{tabular}{ll}
\hline Variabel & p value \\
\hline Berat Badan Lahir < 2500 gram & 0,73 \\
Cara Persalinan & \\
- Seksio tak direncana & 0,05 \\
- Seksio direncana & 0,69 \\
Masa gestasi neonatus $\leq 37 \mathrm{mg}$ & 0,65 \\
Umur Neonatus < 2 mg & 1,00 \\
Jenis Kelamin Laki-laki & $0,03^{*}$ \\
Ada Kelainan Kongenital & $0,05^{*}$ \\
Rujukan & \\
- Lahir luar & $0,00^{*}$ \\
Lama Hari Rawat $\geq 17$ hari & $0,00^{*}$ \\
Long line intravenous catheter & $0,00^{*}$ \\
ETT & $0,00^{*}$ \\
Kateter Umbilicus & $0,00^{*}$ \\
Infus & 0,56 \\
WSD & 0,59 \\
Kateter Urin & 0,57 \\
NGT & $0,00^{*}$ \\
Gastric Tube & 0,70 \\
Kateter Arteri & $0,00^{*}$ \\
Rectal Tube & 0,59 \\
\hline & \\
\hline &
\end{tabular}


Tabel 2. Pengontrolan (Adjusted) Variabel Pemasangan Alat Invasif dengan Variabel Kovariat Lainnya*

\begin{tabular}{lll}
\hline Variabel & $\begin{array}{c}\text { OR Unadjusted } \\
(\mathbf{9 5 \%} \mathbf{C I})\end{array}$ & $\begin{array}{c}\text { OR Adjusted } \\
\mathbf{( 9 5 \%} \mathbf{C I})\end{array}$ \\
\hline $\begin{array}{l}\text { ETT } \\
\text { - Menggunakan }\end{array}$ & $1,85(0,69-5,02)$ & $1,22(0,61-2,47)$ \\
- Tidak menggunakan & $1,12(0,59-2,15)$ & $1,89(0,63-2,24)$ \\
NGT & $1,22(0,73-2,03)$ & $1,16(0,71-1,90)$ \\
- Menggunakan & $1,06(0,11-9,14)$ & $2,30(0,20-27,09)$ \\
- Tidak menggunakan & $1,79(0,25-15,76)$ & $1,19(0,17-8,57)$ \\
Kateter arteri & $1,29(0,76-2,18)$ & $1,25(0,76-2,06)$ \\
- Menggunakan & & \\
- Tidak menggunakan & $4,35(0,81-31,08)$ & $4,31(0,82-0,22,71)$ \\
Long line/Umbilikus & $1,06(0,57-1,99)$ & $1,07(0,59-1,95)$ \\
- Long line iv & & \\
- Infus & & \\
\hline
\end{tabular}

* Umur kehamilan, umur neonatus dan lama hari rawat.

(Lihat tabel 2). Hal ini menunjukkan interaksi antara berat badan lahir dengan penggunaan long line intravenous catheter/ kateter umbilikus. Hasil multivariat pada model akhir terlihat pada tabel 3 .

Dari tabel 3 terlihat efek modifikasi antara neonatus berat badan lahir < 2500 gram dengan pemakaian long line intravenous catheter dan/atau kateter umbilikus terhadap risiko kejadian infeksi nosokomial. Neonatus dengan berat badan $<2500$ gram maupun dengan berat badan $\geq 2500$ gram yang menggunakan long line intravenous catheter/kateter umbilikus memiliki risiko yang cukup tinggi untuk terjadi infeksi nosokomial, sementara neonatus dengan dengan berat badan $<2500$ gram yang hanya menggunakan infus saja, tidak ditemukan risiko untuk terjadi infeksi nosokomial.

Terdapat model akhir dengan dua model. Pada model 1, menunjukkan adanya efek konfonding dari variabel penggunaan NGT, ETT dan kateter arteri pada inter- aksi berat badan lahir ( $<2500$ gram dan $\geq 2500$ gram) yang menggunakan long line intravenous catheter dan/atau kateter umbilikus terhadap kejadian infeksi nosokomial. Sementara pada model 2 juga menunjukkan adanya efek konfonding dari variabel umur kehamilan, umur neonatus, lama hari rawat, cara persalinan, jenis kelamin, kelainan kongenital dan rujukan pada interaksi berat badan lahir ( $<2500$ gram dan $\geq 2500$ gram) yang menggunakan long line intravenous catheter dan/atau kateter umbilikus terhadap kejadian infeksi nosokomial.

\section{Pembahasan}

Kelemahan Desain kasus kontrol yang digunakan adalah rentan terhadap bias seleksi dan informasi. ${ }^{3}$ Bias seleksi telah diupayakan untuk dikendalikan, dengan cara (1) memilih kontrol dari populasi asal yang aktual ( $a c$ tual base population) tempat kasus berasal. Hal ini dilakukan dengan memilih neonatus yang menjadi kelompok kontrol dari level III, (2) kriteria pemilihan kelompok kasus dan kelompok kontrol sama.

Dari hasil kultur didapatkan pola jenis mikroorganisme yang paling banyak adalah bakteri gram negatif dengan jenis kuman terbanyak adalah Serratia sp, Klebsiella pneumonia dan jamur dengan spesies Candida. Serratia $s p$ dan Klebsiella pneumonia merupakan bakteri gram negatif dalam rumpun Klebsiella sp. Peter dan Cashore dalam Remington dan Klein ${ }^{4}$ Menyatakan bahwa sejak tahun 1990-an, epidemik di ruang perawatan intensif neonatus terutama disebabkan oleh bakteri gram negatif seperti Klebsiella pneumonia, Serratia marcescens dan Citrobacter diversus. Penelitian yang dilakukan oleh Pawa et al 5 juga menemukan bahwa pada neonatus dengan infeksi nosokomial, $68 \%$-nya disebabkan oleh bakteri gram negatif jenis Klebsiella $s p$.

Tabel 3. Model akhir pada Hubungan Berat Badan Lahir Bayi dengan Infeksi Nosokomial

\begin{tabular}{|c|c|c|c|c|c|c|}
\hline \multirow[t]{2}{*}{ Variabel } & \multirow[t]{2}{*}{ OR Crude } & \multirow[t]{2}{*}{$95 \%$ CI } & \multicolumn{2}{|c|}{ Model 1} & \multicolumn{2}{|c|}{ Model 2} \\
\hline & & & $\begin{array}{c}\text { OR } \\
\text { Adjusted }\end{array}$ & $95 \% \mathrm{CI}$ & $\begin{array}{c}\text { OR } \\
\text { Adjusted }\end{array}$ & $\mathbf{9 5} \% \mathrm{CI}$ \\
\hline \multicolumn{7}{|c|}{ BBL*Long line kateter umbilikus dan Infus } \\
\hline - Infus $\mathrm{BB}<2500$ & 1,06 & $0,59-1,90$ & 1,01 & $0,55-1,86$ & 1,01 & $0,56-1,84$ \\
\hline - Pakai long line $\& B B \geq 2500$ & 9,78 & $4,48-21,33$ & 8,57 & $3,78-19,42$ & 8,84 & $3,77-20,13$ \\
\hline - Pakai long line\& $\mathrm{BB}<2500$ & 42,42 & $9,77-184,06$ & 35,86 & $8,15-157,92$ & 41,66 & $9,05-191,53$ \\
\hline \multicolumn{7}{|l|}{ Kelompok Alat Invasif } \\
\hline - NGT & 5,48 & $2,20-13,64$ & 3,99 & $1,40-11,37$ & - & - \\
\hline - Kateter arteri & 6,39 & $2,75-14,88$ & 3,76 & $1,48-9,58$ & - & - \\
\hline - ETT & 4,97 & $3,06-8,10$ & 1,57 & $0,91-2,70$ & - & - \\
\hline \multicolumn{7}{|l|}{ Kelompok selain alat invasif } \\
\hline - Umur kehamilan ( $\leq 37 \mathrm{mg}$ ) & 1,11 & $0,71-1,74$ & - & - & 1,33 & $0,70-2,52$ \\
\hline - Umur neonatus $(<2 \mathrm{mg})$ & 1.00 & $0,71-1,74$ & - & - & 1.35 & $0,45-4,12$ \\
\hline - Lama hari rawatan $(\geq 7)$ & 8,27 & $4,97-13,76$ & - & - & 1,18 & $0,69-2,03$ \\
\hline \multicolumn{7}{|l|}{ - Cara persalinan } \\
\hline - Seksio tak direncana & 1,12 & $0,65-1,95$ & - & - & 0,81 & $0,37-1,78$ \\
\hline - Pervaginam & 1,73 & $0,99-3,01$ & - & - & 2,23 & $1,08-4,59$ \\
\hline - Jenis kelamin & 1,64 & $1,05-2,58$ & - & - & 0,99 & $0,58-1,66$ \\
\hline - Kelainan kongenital & 2,03 & $1,02-4,06$ & - & - & 1,12 & $0,53-2,39$ \\
\hline - Rujukan & 2,38 & $1,51-3,75$ & - & - & 0,86 & $0,47-1,57$ \\
\hline
\end{tabular}


Mekanisme pertahanan tubuh neonatus dengan BBL rendah belum sempurna, dan belum siap untuk hidup di luar uterus. Neonatus tersebut biasanya memerlukan perawatan rumah sakit yang relatif lama yang diikuti oleh prosedur invasif. sehingga insiden infeksi nosokomial dapat mencapai 7-25\%.6 Hal ini disebabkan oleh sebagian besar neonatus dengan BBL $<2500$ tidak memenuhi kriteria inklusi yang ditetapkan dalam penelitian ini (seperti ketuban pecah dini lebih dari 18 jam) atau neonatus meninggal/pulang paksa sebelum mencapai usia lebih 3 hari. Selain itu, sebagian besar neonatus yang lahir di luar RSAB Harapan Kita mempunyai BBL $\geq 2500$ gram.

Analisis multivariat menunjukkan bahwa neonatus dengan berat badan $<2500$ gram yang menggunakan long line intravenous catheter dan/atau kateter umbilikus berisiko yang tinggi untuk mengalami infeksi nosokomial. Risiko juga meningkat pada neonatus dengan $\mathrm{BBL} \geq 2500$ gram. Sementara, neonatus dengan BBL < 2500 gram yang hanya menggunakan infus, tidak berisiko infeksi nosokomial. Temuan ini juga sejalan dengan penelitian yang dilakukan oleh Shon et al, ${ }^{1}$ bahwa pemasangan kateter intravaskular sentral memodifikasi efek berat badan lahir rendah terhadap kejadian infeksi nosokomial di ruang perawatan intensif neonatus. Temuan ini bertolak belakang dengan penelitian yang dilakukan oleh Hwang et $a l^{7}$ di ruang perawatan intensif Rumah Sakit Pusat Korea, yang menemukan bahwa penggunaan kateter umbilikus tidak berhubungan dengan kejadian infeksi nosokomial sepsis $(\mathrm{OR}=1,3 ; 95 \% \mathrm{CI}$ :0,82-2,28; $\mathrm{p}=0,23$ ).

Persalinan pervaginam berisiko 2 kali lebih besar untuk mengalami infeksi nosokomial daripada bayi yang dilahirkan dengan seksio sesaria yang direncanakan (95\% CI:1,05-4,17). Neonatus yang lahir pervaginam berisiko untuk terjadi infeksi nosokomial. Donowitz ${ }^{8}$ menemukan Streptokokus grup B pada 2-25\% ibu normal dan sekitar $42-72 \%$ (rerata $58 \%$ ) dari neonatus yang lahir pervagina ibu yang terkolonisasi mikroorganisme tersebut terjangkit mikroorganisme.

\section{Kesimpulan}

Kuman yang paling banyak ditemukan pada infeksi nosokomial di ruang Perinatalogi RSAB Harapan Kita adalah bakteri gram negatif yang meliputi Serratia sp, K Pneumonia dan Candida. Persalinan pervaginam berpeluang infeksi nosokomial 2 kali lebih besar daripada bayi yang dilahirkan dengan persalinan seksio sesaria yang direncanakan. Penggunaan NGT, kateter arteri ber hubungan bermakna dengan infeksi nosokomial, tetapi pemasangan ETT tidak berhubungan bermakna dengansi nosokomial. Neonatus dengan berat badan $<2500$ gram yang menggunakan long line intravenous catheter dan/ atau kateter umbilikus berhubungan bermakna dengan infeksi nosokomial. Risiko tersebut meningkat pada ne- onatus dengan $\mathrm{BBL} \geq 2500$ gram, sementara neonatus dengan $\mathrm{BBL}<2500$ yang hanya diinfus, tidak berisiko infeksi nosokomial. Ada hubungan antara BBL dengan kejadian infeksi nosokomial yang dimodifikasi oleh pemasangan long line intravenous catheter dan/atau kateter umbilikus, setelah dikontrol variabel lain.

\section{Saran}

Pemasangan alat invasif, terutama long line intravenous catheter dilakukan secara selektif. Terapkan kaidah aseptik, terutama kebiasaan mencuci tangan sebelum dan sesudah menangani pasien. Perlu dipertimbangkan menambah jumlah perawat yang bertugas saat pasien meningkat, guna mempertahankan tehnik aseptik dalam melakukan perawatan neonatus. Pencantuman diagnosis infeksi nosokomial pada rekam medik efektif untuk meningkatkan pelaksanaan surveilans pengendalian infeksi nosokomial, yang dilanjutkan dengan sosialisasi hasil surveilans infeksi nosokomial, sehingga dapat diketahui bahwa rumah sakit telah berusaha untuk mengendalikan masalah infeksi nosokomial. Perlu dilakukan penelitian serupa dengan disain studi Kohort dan perhitungan berat badan yang disesuaikan dengan umur kehamilan dan resistensi kuman terhadap antibiotika. Melakukan penelitian dengan kategori berat badan lahir $<2500$ gram, karena daya tahan neonatus yang dirawat di RSAB Harapan Kita cukup tinggi.

\section{Daftar Pustaka}

1. Shon, et al. "Prevalence of Nosocomial Infection in Neonatus Intensive Care Unit Patient: Result from the First National Point-Prevalence Survey”. The Journal of Pediatric, 139, December 2001:821-827.

2. Rahayu. Gambaran Epidemiologi Infeksi Nosokomial di Ruang Rawat Inap Anak RSAB Harapan Kita tahun 1997-1999. Skripsi. Fakultas Kesehatan Masyarakat Universitas Indonesia, Depok, 2000.

3. Zheng, Tongzhang. Principles of Epidemiology. Yale University School of Public Health, 1988.

4. Peter, Georges \& William Cashore. Infections Acquired in the Nursery: Epidemiology and Control. Dalam: Jack S. Remington, M.D. \& Jerome O. Klein, M.D. "Infectious Diseases of the Fetus and Newborn Infant”. W.B. Saunders Company, 1990.

5. Pawa \& Ramji. "Risk Factors of Nosocomial Infection in Neonatal Intensive Care Unit”. The Journal of Infectious Diseases, Vol.147, No. 4, April 1984:356-364.

6. Satari \& Amalia, Lia. Pengendalian Infeksi nosokomial di Rumah Sakit Dalam : Akib AAP, Tumbelaka AR, penyunting. Pendekatan Imunologis berbagai penyakit alergi dan infeksi. Naskah Lengkap Pendidikan Kedokteran Berkelanjutan Ilmu Kesehatan Anak XLIV. Balai Penerbit FKUI, Jakarta, 2001.

7. Hwang, Jong Hee. "The Efficacy of clinical strategies to Reduce nosocomial Sepsis in Extremely low Birth Weight Infants". J Korean Med Sci. Vol.20, 2005: 177-181.

8. Donowitz, L.G. Infection In The Newborn. Dalam : Wenzel, R.P. (1993). Prevention and Control of Nosocomial Infection". Williams \& Wilkins. Baltimore, 1993. 